\title{
Dysfunctional Glucocorticoid Receptors in Acute Leukemia *
}

\author{
R. Bell, A. Lillquist, S. Cotter, S. Sallan, and R. McCaffrey
}

\section{A. Introduction}

The obligatory role of specific cytoplasmic receptors as mediators of steroid hormone action is well established. In lymphoid cell culture systems the development or glucocorticoid resistance is almost always due to a mutation to a receptor negative state [1]. Therefore, if the assumption is that glucocorticoid-induced remission in leukemia is by a direct effect on leukemic blast cells, one would predict that the presence of absence of blast cell glucocorticoid receptors would be a major determinant or clinical steroid sensitivity. However, receptor quantization has not correlated with steroid responsiveness [2-5], and in particular, high receptor numbers are not uniformly associated with responsive disease [6].

We have speculated that this lack of concordance between receptor status and clinical outcome may be due to the presence of glucocorticoid binding macromolecules which are physiologically nonfunctional in those leukemias which are glucocorticoid resistant. To test this hypothesis, we have studied certain biochemical and biophysical characteristics of glucocorticoid binders in normal and leukemia cells, to determine if such dysfunctional binding macromolecules exist, and to establish their relationship to therapeutic outcome.

\footnotetext{
* Supported by Grant CA288818 from the National Institutes of Health and the Irving Mann Medical Oncology Research Endowment Fund
}

\section{B. Materials and Methods}

\section{Cells and Tissues}

\section{Normal Tissues}

Thymus, spleen, and lymph node from 3-5 day old calves were obtained at a local slaughter house. Bone marrow mononuclear cells were harvested from 12-week-old BALB/C mice. Human thymus was obtained from a 7-year-old child undergoing cardiac surgery. Human peripheral blood lymphocytes were harvested on LSM from CPD anticoagulated whole blood from normal adults [8].

\section{Leukemia Cells - Humans}

Seventy-eight patients with acute leukemia were studied, 73 at first presentation prior to any therapy, and five at first relapse prior to attempting reinduction therapy. No patient had received steroid medication within 2 weeks of study. Thirty-five had acute lymphoblastic leukemia (ALL) (31 new cases, 4 relapses), 25 had acute myelogenous leukemia (AML) (24 new cases, 1 relapse), and 18 had the blast crisis of chronic myelogenous leukemia (CML). The patients ranged in age from 3 years to 72 years. Samples with less than $75 \%$ blast cells were not studied. Blast cells were harvested from EDTA-anticoagulated venous blood (61 patients), bone marrow aspirate (11 patients), or both (six patients).

\section{Leukemia Cells - Animals}

Cells and tissues from 38 domestic cats and 21 dogs with lymphoblastic leukemia - 
lymphoma were studied at the Angell Memorial Hospital, Boston, MA. All animals were newly diagnosed and none had received therapy prior to study. Blast cells were harvested from EDTA-anticoagulated LSM-sedimented venous blood or marrow (18 animals) or from histologically involved nodes (41 animals). Twenty-four of these animals were treated with single agent prednisone $2 \mathrm{mg} / \mathrm{kg}$ p.o. $\times 14$ days and their response evaluated by standard clinical criteria.

\section{Analytical Procedures}

The cytosol preparation and labeling procedures used were modified from the broken cell labeling system of Sakaue and Thompson [7], as previously described [8]. The analytical procedures have been described in detail [8].

\section{Results}

\section{Normal Tissues}

${ }^{3} \mathrm{H}$-Triamcinolone acetonide labeled glucocorticoid receptors in normal lymphoid tissues can be resolved into two components by DEAE chromatography: Peak I elutes at $0.04 M$ salt and peak II at $0.22 M$ salt. Figure $1 \mathrm{~A}$ shows the elution profile of labeled receptors from human peripheral blood lymphocytes. By glycerol gradient centrifugation peak $I$ is $3.5 \mathrm{~S}$ and peak II 8.5S. Peak I binds to DNA while peak II has negligible binding. After heat activation peak II alters its coefficient of sedimentation to $3.5 \mathrm{~S}$, changes its elution position to $0.04 M$ salt (peak I area) on DEAE chromatography, and acquires affinity for

Table 1. Glucocorticoid binders in human acute leukemia

\begin{tabular}{lrrrr}
\hline $\begin{array}{l}\text { DEAE } \\
\text { chromatography }\end{array}$ & ALL & AML & CML Total \\
\hline $\begin{array}{l}\text { Normal - two peak } \\
\text { Abnormal - single }\end{array}$ & 6 & 10 & 14 & 30 \\
peak & 35 & 25 & 18 & 78 \\
\hline Total & & & & 48 \\
\hline
\end{tabular}
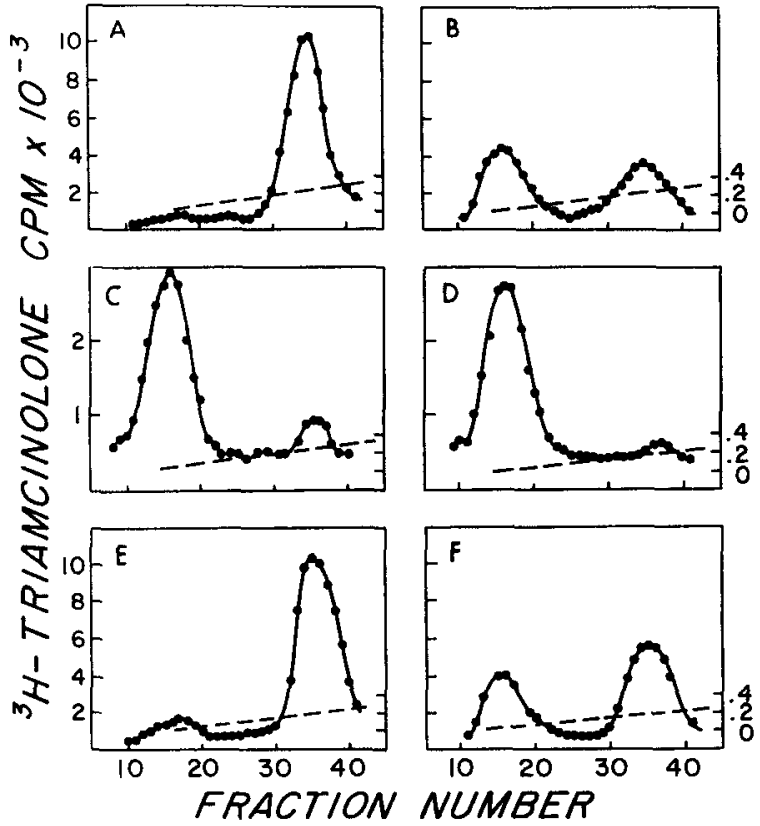

Fig. 1A-F. DEAE chromatography of ${ }^{3} \mathrm{H}-\mathrm{TA}$ labeled glucocorticoid receptors from unheated and heated cytosols. A represents the chromatogram obtained from human peripheral blood mononuclear cells; $B$ the chromatogram obtained after heating this cytosol $\left(20^{\circ} \mathrm{C}\right.$ for $20 \mathrm{~min}$ ); $\mathrm{C}$ the chromatogram derived from a case of childhood AML with abnormal single peak pattern; $\mathbf{D}$ the chromatogram obtained after heating of this cytosol before DEAE chromatography; $\mathbf{E}$ the chromatogram obtained from a case of childhood ALL; F the chromatogram obtained after heating of this cytosol

DNA (Fig. 2A). The DEAE elution profile of labeled receptor from peripheral blood lymphocytes which had been heated at $20^{\circ} \mathrm{C}$ for $30 \mathrm{~min}$ is shown in Fig. $1 \mathrm{~B}$.

\section{Human Leukemia}

In 48 of 78 cases of human leukemias, blast cell ${ }^{3} \mathrm{H}$-TA binding macromolecules had characteristics identical to those found in

Table 2. Glucocorticoid binders in animal lymphoblastic disease

\begin{tabular}{lllc}
\hline DEAE pattern & $\begin{array}{l}\text { Re- } \\
\text { sponders }\end{array}$ & $\begin{array}{l}\text { Non-re- } \\
\text { sponders }\end{array}$ & Total \\
\hline $\begin{array}{l}\text { Normal } \\
\text { Peak I - peak II }\end{array}$ & 9 & 9 & 18 \\
$\begin{array}{l}\text { Abnormal } \\
\text { Single peak }\end{array}$ & 0 & 6 & 6 \\
\hline Total & 9 & 15 & 24 \\
\hline
\end{tabular}




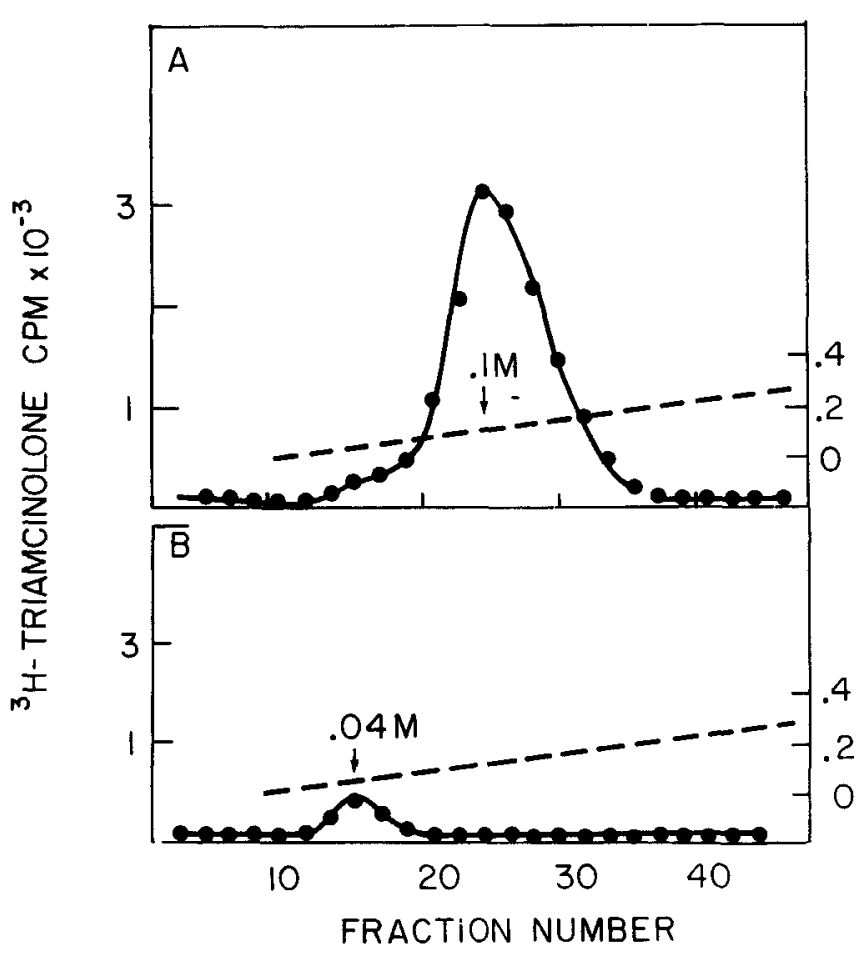

Fig. 2 A, B. DNA cellulose chromatography of peak I material from heated cytosols. A The elution from DNA cellulose of heat-activated peak I complexes from a case of childhood ALL with the normal tissue DEAE pattern. B The elution from DNA cellulose of heated peak I material from a case of childhood AML with the abnormal single peak pattern normal tissues (Fig. 1E, F). The receptors from the remaining samples were abnormal (Table 1). The abnormality (30 cases) was the presence of only a single DEAE species eluting in the peak I area (Fig. IC, D), which was $2.5 \mathrm{~S}$ and failed to bind to DNA with or without activation (Fig. $2 \mathrm{~B}$ ). In two experiments, leukemic cells with the normal DEAE pattern were mixed in a one-toone ratio with cells showing the abnormal single peak pattern. The binders maintained their identities in this experiment: the "mixed" chromatogram showed peak I and peak II in an additive ratio, suggesting that the single peak pattern is not a product of the labeling or analytic procedures (data not shown).

\section{Animal Lymphoblastic Disease}

Abnormal ${ }^{3} \mathrm{H}$-triamcinolone binding macromolecules of the sort seen in human leukemia were identified in the blast cells of 13 of 59 (22\%) cats and dogs with this disease; the remaining 46 animals had normal receptors by our criteria. To data, in a prospective blind study 24 aminals (18 with normal receptor patterns, 6 with abnormal glucocorticoid binders) have been treated with prednisone, $2 \mathrm{mg} / \mathrm{kg}$ per day $\times 14$ days p.o. None of the six animals with $a b-$ normal binders responded, whereas 9 of the 18 with normal receptor characteristics did (Table 2).

\section{Discussion}

The 78 human leukemic samples we studied by these techniques segregated into two groups: those with normal tissue binder characteristics (48 cases) and those with abnormal binders (30 cases). Normal and abnormal patterns were noted in all three acute leukemia variants (Table 1). Similarly, abnormal binders were found in the blast cells of 13 of 59 domestic animals with lymphoblastic leukemia-lymphoma. In the abnormal cases, the ${ }^{3} \mathrm{H}-\mathrm{TA}$ labeled binders eluted as a single species from DEAE in the peak I $(0.04 M$ salt $)$ region. The abnormal single peak material did not bind to DNA cellulose, whereas the affinity of peak I material for DNA cellulose was normal in cases in which the initial DEAE profiles were normal. In four of four cases studied, the abnormal single peak DEAE patterns had peak I-peak II S values identical to those of normal tissues (3.5S and $8.5 \mathrm{~S}$, respectively). Thus, while the abnormal single peak material cannot be distinguished from normal peak I complexes by DEAE chromatography alone, further characterization on DNA cellulose and glycerol gradients clearly differentiates between the two forms.

Our speculation is that leukemias with abnormal binder characteristics may be incapable of responding to glucocorticoid 
therapy. The 78 patients in our series all received multiple agent chemotherapy, and we have therefore made no attempt to correlate clinical outcome with receptor characteristics. In the animal study, none of six animals with abnormal binder characteristics responded. Thus, the abnormalities we have identified to date may provide a biochemical basis for one form of glucocorticoid resistance. Other defects in receptor physiology are now being sought. The establishment of a clearly defined responder phenotype for glucocorticoid receptors in leukemia cells would permit restriction of the use of glucocorticoids to those patients in whom such receptors could be identified, thus eliminating unnecessary exposure to what may sometimes be serious systemic glucocorticoid toxicity. The ability to unequivocally identify physiologically functional receptors would also allow a rational pursuit of a detailed molecular investigation of the mechanisms involved in steroid-induced remissions in leukemia.

\section{References}

1. Bell PA, Junes TR (1979) Cytoplasmic receptors for glucocorticoids. In: Bell PA,
Borthwick NM (eds) Glucocorticoid action and leukaemia. Alpha Omega, Cardiff, p 1

2. Homo F, Duval D, Meyer P (1975) Etude de la liason de la dexamethasone tritiee dans les lymphocytes de sujets normaux et leucemiques. Compt Rend 280:91

3. Crabtree GR, Smith KA, Munk A (1978) Glucocorticoid receptors and sensitivity of isolated human leukemia and lymphoma cells. Cancer Res 38:4268

4. Longo $\mathrm{P}$, Mastrangelo R, Ranelletti RO (1979) Childhood acute lymphoblastic leukaemia: Glucocorticoid receptors, in vitro corticosensitivity and responsiveness to therapy. Cancer Treat Rep 63:1197

5. Iacobelli S, Mastrangelo R, Zenobi R, Ranelletti FO (1979) Paradoxical effects of glucocorticoids of human leukaemic cells in vivo and in vitro. In: Bell PA, Borthwick NM (eds) Glucocorticoid action and leukaemia. Alpha Omega, Cardiff

6. Mastrangelo R, Malandrino R, Riccardi R, Longo P, Ranelletti FO, Iacobelli S (1980) Clinical implications of glucocorticoid receptor studies in childhood acute lymphoblastic leukemia. Blood 56: 1036

7. Sakaue Y, Thompson EB (1977) Biochem Biophys Res Com 77:553-561

8. McCaffrey R, Lillquist A, Bell R (1981) Biochemical and biophysical characterization of glucocorticoid receptors in normal lymphoid tissues. Blood 58:263 